\title{
COLLEGE STUDENT AND SOLDIER BOY
}

\section{By ORA WILliams}

The little blank book lying on the desk is not very attractive. It is the kind schoolboys used a century ago, with board covers and thin ruled paper, nice for a diary or a secretary's record. This one was used for both. There is writing in it, plain and quite varied as to topics. There is a date on the title page-October 14, 1859. The place Anamosa, Iowa. The book was to be a record of the "Constitution and By-laws of the Excelsior Debating Club" and of the club's activities for about one year. Then the secretary of the club started off to college at Mt. Vernon, Iowa. After another year an important entry was made, followed by a much later one in the writing of the same man. These two entries tell a big story. They are:

Anamosa, Iowa, Oct. 12th, 1861. President Lincoln calls for 300,000 men. I enlisted today in Union army for 3 years. Later-I am 2nd corporal of Co. H, 14th Iowa Vols; Wm. T. Shaw of Anamosa, colonel. Charles W. Hadley.

Later, June 1st, 1923, Ogden, Utah. Still on earth a little the worse for wear, but no fault to find. CHas. W. HADLEY.

That covers sixty-two years of one life. The story of the years can be filled in by anyone. Doubtless it was typical. Certainly it was eventful and useful. Probably, also, the best part of it was covered in this brief story found in the Roster of Iowa Soldiers, Vol. 2, in connection with the personnel of the 14th Iowa Infantry:

Charles W. Hadley, Age 18. Residence, Anamosa, nativity, New Hampshire. Enlisted Oct. 12, 1861 as Fifth corporal. Mustered Nov. 6, 1861. Missing in action April 6, 1862, Shiloh, Tenn. Discharged for disability March 23, 1863 at St. Louis, Mo. Re-entered service Oct. 12, 1864. Mustered out Nov. 16, 1864 at Davenport, Iowa.

At the age of eighty and far beyond, Corporal Hadley recalled the hurried assemblage of Iowa boys of his home county of Jones, the crowding into a steamboat at Daven- 
port less than four weeks after enlistment, the little drilling and maneuvering for six weeks at Benton Barracks, thence in the middle of winter via the Mississippi, the Ohio, and the Tennessee and on to Fort Donelson; then the conflict with the Confederates of which Colonel Shaw reported, "I have never seen men behave themselves better, whether under fire or bearing with patience and fortitude the fatigue and hardships necessarily incident to so long an engagement in such weather." Then followed the march south and the battles of Pittsburgh Landing and Shiloh, and the capture of Colonel Shaw and a part of his regiment; later the service at Vicksburg and in western Missouri. The service covered a little more than three years. The praise extended by Col. Wm. T. Shaw came from one well qualified to speak, for he had been a volunteer private in the Mexican war.

\section{AT THE THRESHOLd OF LIFE}

Now let us see what if anything this little note book and diary of a college boy reveals as to what was in his heart at the threshold of life. The Excelsior Debating club was much like thousands of others of the time. The first report of a debate was dated Oct. 21, 1859. The question was, "Resolved, that the United States should extend her limits." The boy Hadley did not get in on this discussion of internationalism or imperialism or whatever it should be called. A week later it was, "Resolved, that woman should have the same rights and privileges as man." Hadley was on the affirmative and records that the negative won. Some time later it was "Resolved, that the principles of the No-nothing party were correct." Here one should go to the encyclopedia and read up on the "Know-nothing party" and its principles. Hadley was on the affirmative and they won. Other topics of discussion were that "fashion has been the cause of more evil than good," that "the pulpit has exerted a greater influence than the press," and that "the works of art are more pleasing to the eye than those of nature." 
Then in December the club had before them this highly controversial question, "Resolved, that the motives by which John Brown was actuated were right." Hadley was on the team for the affirmative, but records that the decision was against him. He was evidently disposed to an independent course. For a boy of fifteen he was getting started at doing his own thinking. There must have been some warm feelings aroused at this debate. Four members who had been assigned to the debate, backed out and were fined for so doing. They then raised the fines from ten cents to twenty cents. And it "has never met since" is the last entry about the club.

Through this little book, now converted into a personal record, we follow young Hadley in September of 1860 from Anamosa to Mt. Vernon "riding half a day through mud." His father accompanied him and saw him located in a room in the home of a Mr. Spangler back of the hotel at $\$ 2.25$ a week for board and room. He found at Cornell college that there are "two societies in operation" and there were six teachers. One of his first entries was: "The Republican club met last night and being chosen to make a speech did so and was appointed to help draft a constitution and by-laws."

In the Excelsior club, Hadley had put himself in training for participation in current politics. He was to follow this line to a conclusion. Very soon he records that he was elected "to membership in the Amphiction Society, which I was glad to hear, although it takes another dollar out of my pocket." Some of the students went to Iowa City to the fair, but he did not go. He saved his money and bought a flute. He reports that on Oct. 5 he "will attend the Amphiction Society this evening for the first time and tomorrow night the Lincoln and Hamlin club." Later he records having helped prepare the papers for the latter club. He was not neglecting his grammar, his algebra and his Latin and German; but in the midst of such a political campaign it was natural to expect college students to discuss politics.

Before the close of his third week at college he was 
deep in politics. "Douglas, I understand, is to speak at Cedar Rapids and also at Anamosa in evening." He heard a good speech by Milo Smith at the republican meeting. At the Amphiction he participated in debate on the assertion that "the press should be without legal restrictions." But he is getting the fever and learns that "some of the students went to Iowa City to hear the Little Giant speak," but he argues with himself "whether or not to go to Cedar Rapids tomorrow and hear him myself. I will dream over it and decide in the morning. Most all of the students are going. My chum is going. I guess I shall have to go." The next day he went with the others, for the fame of the Little Giant (Stephen A. Douglas) as an attractive and persuasive orator had reached into Iowa as far as the Cedar river.

The Cornell college contingent arrived by train in the forenoon and the Little Giant did not show up until noon. "He was received with cheers although over half present were Republicans. He commenced speaking about onethirty o'clock and spoke fifty-five minutes, after which Dodge spoke a few minutes. Douglas is about five feet, six inches in height, large head, round face, is quite red in the face, has a very good voice although much damaged by constant exertion, he is very graceful in gesture. A vote was taken upon the cars which resulted in Douglas receiving ninety-nine votes, Lincoln one hundred eleven, Bell three, among the men. Among the ladies Douglas twenty-four, Lincoln twenty-five, Bell one. More Republicans went to hear a Democrat speak than Democrats. Hurrah for Lincoln and Hamlin."

IMPERSONATES A NEGRO

Politics and other things were mixed in Hadley's room. He went to Lisbon to get some marbles for balloting at the Amphiction. He wrote that Lisbon resembled ancient Rome only he judged it was set on seventeen hills instead of seven, and was a mile long and about twenty rods in width. There was a political meeting in Lisbon and it "was a grand fizzle." Then one evening Hadley tried something else: 
"Last night I had more sport than I have had for one year. I blacked my face and rigged up like a negro and went all over the town to see if any of the Republicans would keep me. Everybody had so little room that they could not keep me. They all directed me to the negro barber. Nobody suspected but I was a real negro."

He had a welcome call from his brother Frank who brought him a pair of boots and a pair of pants, and on November 7 he reports:

"Yesterday was election day. Lincoln carried the day by 100 majority. At Cedar Rapids he had a majority of 150 . There was very little excitement here yesterday. It was the most quiet election day for president I ever saw. Anamosa has gone Douglas, though not a very large majority. While writing I hear three cheers down town for somebody; I suppose for Lincoln. My opinion is that he is our next president. I guess I will go down and see what the rumpus is. I have just returned from the street. They had a bonfire and were making speeches. They called for me but I did not feel like speaking, so I declined. The bell is now ringing for nine o'clock. I heard this evening that Chicago had gone 2,000 majority for Lincoln."

Five days later the "news of the election is still coming in. Lincoln is ahead. Hurrah for Lincoln." This closed the political record.

Young Hadley did not remain at Cornell college after the close of the year. His journal discloses that he was very busy with lessons and debates and compositions. He had a touch of social interest. The students sent a petition to the faculty asking for a "promenade" which was put off, but at a later time opportunity was given, just once, for the boys and girls to meet. The situation was thus described:

"Well! We are not allowed to see the girls at their rooms nor walk out with them, in fact are not allowed to have anything to do with them. Once or twice a term the young men get up a petition asking for a promenade which is generally granted. They set some night, then 
the students all meet at the chapel, select their partners and commencing pacing the hall back and forth, then is formed a double row one moving one way and the other the opposite. Changing of partners is another characteristic. A young fellow desirous of changing introduces his lady to the other and the other returns the compliment. An exchange is thus made. It is seldom that a fellow can keep his lady until he gets twice around the hall. If he is introduced he is duty bound to exchange. This is not always the case though. Sometimes they get one that they can't get rid of. I engaged myself first rate last night. I had the honor of having the company of two of the nicest girls in the town and that is saying a good deal."

School DaYs ENDED-ARMy SERvice Begins

But there was doubt about the financial ability of Hadley to remain at Cornell, and in January we find him teaching school in Cass township, Jones county at $\$ 18.00$ a month and board. His schooling days were over.

Then came a final entry. It is not dated, but was certainly within a few weeks. He wrote: "South Carolina has withdrawn from the Union. She has fired upon a ship sent by the President to reinforce Fort Sumpter. Mississippi has also gone. Other states are threatening to do the same. Let 'em went!"

Then the final journal entry relating his own enlistment under Col. Wm. T. Shaw. Then the entry of sixtytwo years later in the same hand. The little book discloses some other things about the boy who went from Anamosa to college at Mt. Vernon. He had bought a flute and was inclined to music. He copied into the book a few bars of music listed as "Hadley Favorite 1835," for flute. He copied in pencil a number of old songsBelle Brandon, My Home in Old Kentuck, Gentle Annie, Nelly Gray, Old Folks at Home, and others. He attended chapel regularly and made a list of Bible references in the book. But he loved politics, and near the close of the book he gave a list of states and their pluralities for Fremont or for Buchanan in the last previous election. 
College life is different now; also army life is something that would have seemed fantastic to young Charles W. Hadley, student at Cornell college of Iowa.

The book was sent to the Historical department by a man in Idaho who seems to have been connected in some way with the W. P. A. work, but had been a resident of Ogden, Utah.

\section{GOOD SOLDIERS-BAD GUNS}

A strange coincidence at the desk of THE ANNALS editor illustrates anew how the currents of history cross and re-cross. About the time of receipt of the journal above mentioned, by one who early enlisted in the Fourteenth Iowa regiment, two other blank book records came without solicitation to the Historical department relating to the same Iowa regiment of volunteers. These were a book in which was recorded the names of all members of the regiment, with enlistment and other facts; the other a book in which it was evidently intended to keep a complete record of the regiment and all correspondence relating thereto. These books were sent to Iowa by the Rev. Arthur Heeb, pastor of the Unitarian church, Northfield, Mass. They were found by Mrs. Charles E. Leach, of that city, "in an auction job lot."

Internal evidence suggests that probably these books were seized by the Confederate army at the battle of Shiloh, where Col. Shaw was taken prisoner, and that never before were they in Iowa.

There is revealed in the books a controversy that shows some of the difficulties the Union armies encountered in getting started to win the Civil war. This is the story of Iowa volunteers going almost direct from the farms and shops into battle armed with imperfect weapons, and the serious effort of an Iowa colonel and an Iowa governor to see that Iowa men were properly equipped.

The first entry in this letter book is copy of a letter dated Dec. 27, 1861, at St. Louis arsenal, addressed to Col. Wm. T. Shaw, stating that Col. F. P. Callender encloses an invoice of ordnance and ordnance stores turned 
over to the quartermaster's department for the 14th Iowa. Following this is the reply from Col. Shaw as follows :

"Headquarters 14th Regiment, Iowa infantry, Benton Barracks, Mo. Dec. 30th, 1861. Lt. Col. F. P. Callender, Sir: Yours of Dec. 27 th rec'd and in reply will state that the arms forwarded me have been thoroughly tested, and condemned as unfit for service. They are now in my possession, and will be held subject to your order. Enclosed please find receipt and duplicate, which I return to you, as I refuse to receipt for imperfect arms. Yours very respectfully, WM. T. SHAW, Com. 14th Reg. per N. N. TyNer, Adjt."

That was sharp and to the point. Back of it is a story worth recalling in this newer period of a different kind of warfare. It is elsewhere revealed in this regimental record book that when the Iowa colonel first asked for arms he was invited to "call at the arsenal and let me show you the arms I can furnish before the issue is made," but there is nothing to show what happened at that time. But it seems probable that Col. Shaw protested that the arms offered were not good, for he copies a letter from Gov. Samuel J. Kirkwood to him dated Dec. 27, saying, "don't take those old muskets if you can possibly avoid it."

Later the colonel made a report to Brigadier General Wm. T. Sherman as follows:

"Having made a requisition on the ordnance department for arms and accoutrements for 601 men, I received from Colonel Callender a number of packages invoiced 'Austrian Rifle Muskets.' Captain Shannon, of Co. E, 14th Iowa Vol., upon a verbal order from you, took forty pieces to try their accuracy of range. He reported to me that he had tried them, that they shot wide of the mark, that several of the tubes had broken or burst and many of the locks were worthless. I then requested Major Leonard of my command to take 40 and test their strength of barrel. He reported having tested them 'with two or three service charges, and that eighteen of the forty burst and that he considered them unsafe and worthless. I ordered them re-boxed and notified Col. Callender that they awaited his order, as I considered them unsuitable for service. Subsequently they were further tested by a commission appointed by yourself, with about the same result as the test by Major Leonard and Captain Shannon. I think from the great anxiety on the part of persons connected with the ordnance department to force these arms upon the troops, regardless of the 
interest of the service, that it would be a proper subject for the commanding officer to enquire into, and see if there were not individual interests which prompted such action on the part of persons connected with said department."

\section{DEFECTIVE AND WORTHLESS ARMS}

There is in the letter book correspondence relating to other matters not pertinent to this story of the worthless arms, as to a misunderstanding about where the regiment was to be sent, and as to a shake-up in one company as the result of a personal quarrel of some members. But there is more about the guns. The complete and detailed report of the gun tests by Captain Shannon is copied. Then a letter to Major General Halleck late in January closes the incident:

"On my requisition for arms I received from the ordnance department guns invoiced 'Austrian Rifled Muskets,' many of which are unserviceable from defective locks, tubes, etc. They are an inferior arm and $I$ do not think two-thirds of them can be relied on as effective. The arms have been condemned by a board of officers appointed at Benton Barracks Dec. 31, 1861, special order No. 108. They were afterwards distributed by order of Gen'l. Sherman dated Jan. 10, 1862 stating that was the best that could be done at that time. This report is made by request of Brigadier General Sherman."

To get the full import of this brief correspondence, a little of the history of the regiment should be told. Col. Wm. T. Shaw was a resident of Anamosa, Jones county. He was a veteran of the Mexican war. There were enlistments from nearly every eastern Iowa county. Recruiting was in October and November. Three companies were detached and sent north. Seven companies were mustered Nov. 3-7, 1861 at Davenport. Late the same month the seven companies were taken by steamboat to St. Louis. They were at Benton Barracks two months getting ready for service.

On February 5, 1862 the Fourteenth Iowa regiment took to the river again and went to Cairo and Fort Ifenry. By February 13 the regiment faced a Confederate army at Fort Donelson and had its first baptism of blood. 
Later, at Shiloh the regiment was badly used and its colonel and many of the men fell into the hands of rebels.

It would thus appear that barely two months after these raw recruits from Iowa farms saw their first guns they were in battle. In the meantime they had seen something of what was ahead, for the regiment paused for a time at Cairo, where many of the soldiers who had suffered defeat at Bull Run had been sent and some to perish for lack of care. It was here that Mother Wittenmyer took over the care of the sick and wounded.

Colonel Shaw made his report on the various battles in which he was engaged after his parole from prison.

Was there any connection between the defective "Austrian Rifled Muskets" that the colonel flatly refused to accept, but which he was compelled to use, and the fate of the regiment at Shiloh?

There is no answer in the letter book of Colonel Shaw. His regiment lost 273 men at Shiloh. When ammunition was exhausted and he was surrounded, Colonel Shaw surrendered. A year later he was back at the head of his regiment and on the way to Vicksburg.

\section{MILD WINTER IN IOWA 69 YEARS AGO}

Mrs. L. B. Schmidt of Ames discovered in reading the old diary kept by her father, W. A. Wilson, pioneer of Kossuth county, that 75 years ago Jan. 18th, the temperature registered 78 degrees. It was an open winter. He also recorded that wild geese were flying over. This daily recording of events by $\mathrm{Mr}$. Wilson covered a period of years from 1850 to 1898 , until the time of his death.Story City Herald. 
Copyright of Annals of Iowa is the property of State of Iowa, by \& through the State Historical Society of Iowa and its content may not be copied or emailed to multiple sites or posted to a listserv without the copyright holder's express written permission. However, users may print, download, or email articles for individual use. 